Article

\title{
Income Change and Inter-Farmer Relations through Conservation Agriculture in Ishikawa Prefecture, Japan: Empirical Analysis of Economic and Behavioral Factors
}

\author{
Yoshitaka Miyake $^{1}$ (D), Shota Kimoto ${ }^{2}$, Yuta Uchiyama ${ }^{3}$ (D) and Ryo Kohsaka ${ }^{1, *(D)}$ \\ 1 Graduate School of Environmental Studies, Nagoya University, Nagoya 464-8601, Japan; \\ miyake.yoshitaka.m8@f.mail.nagoya-u.ac.jp \\ 2 Ishikawa Prefectural Government, Kanazawa 920-8580, Japan; kshota@pref.ishikawa.lg.jp \\ 3 Graduate School of Human Development and Environment, Kobe University, Kobe 657-8501, Japan; \\ yuta.uchiyama@landscape.kobe-u.ac.jp \\ * Correspondence: kohsaka@hotmail.com
}

Citation: Miyake, Y.; Kimoto, S.; Uchiyama, Y.; Kohsaka, R. Income Change and Inter-Farmer Relations through Conservation Agriculture in Ishikawa Prefecture, Japan: Empirical Analysis of Economic and Behavioral Factors. Land 2022, 11, 245. https:// doi.org/10.3390/land11020245

Academic Editor: Elisa Marraccini

Received: 17 January 2022

Accepted: 3 February 2022

Published: 6 February 2022

Publisher's Note: MDPI stays neutral with regard to jurisdictional claims in published maps and institutional affiliations.

Copyright: (C) 2022 by the authors. Licensee MDPI, Basel, Switzerland. This article is an open access article distributed under the terms and conditions of the Creative Commons Attribution (CC BY) license (https:// creativecommons.org/licenses/by/ $4.0 /)$.

\begin{abstract}
Conservation agriculture, also known as environment-friendly agriculture, is expected to contribute to global climate change mitigation and biodiversity conservation. To understand the effect of conservation agriculture on farmers and identify those factors, such as farmers' income change, that might affect practices of conservation agriculture, perceptions, and output, this study examined farmers' economic and behavioral factors, motivation, and satisfaction. We surveyed 51 farmers who are receiving subsidies to practice conservation agriculture in Ishikawa Prefecture, Japan. The survey is one of the first prefectural-scale studies that combines unique quantitative analysis of motivation and satisfaction levels (e.g., behaviors) in temporal sequence from the initial to current time to practice conservation agriculture. Our results showed that years of experience, trade with a retail shop, and the farmer's age can affect income change. With regard to social factors, the satisfaction of their fellowship with other farmers practicing conservation agriculture was also significantly correlated with income change. Simultaneously, this category of satisfaction was difficult to attain compared to the other categories. Thus, greater effort is needed to enhance support networking among conservation farmers. Furthermore, the work presented here also provides the opportunity for future research on temporal and spatial questions surveying economic and behavioral effects with consideration of the heightened policy promotion and entrance of large retail industries.
\end{abstract}

Keywords: organic agriculture; environment-friendly agriculture; regression tree; attitude; motivation; satisfaction

\section{Introduction}

Conservation agriculture, also known as environment-friendly agriculture, is regarded as a farm-level attempt to use agricultural practices that contribute to the protection of the environment via biodiversity conservation, water quality enhancement, and climate change mitigation and adaptation [1-3]. Thus, this study utilizes a broader-focus definition of conservation agriculture than the definition used by the Food and Agriculture Organization of the United Nations, which primarily emphasizes the control of soil erosion [4]. The intention to use a definition with a broader focus is closely related to Direct Payment for Conservation Oriented Agriculture (Kankyō Hozengata Nōgyō Chokusetsu Shiharai Kōfukin in Japanese), the Japanese policy of direct payment focusing on the reduction of chemical fertilizer and pesticide while supporting agricultural practice to conserve biodiversity with the recent addition of climate change mitigation measures [5]. Thus, the use of the term, conservation agriculture, is appropriate to analyze agriculture to preserve the environment in Japan, especially biodiversity conservation. The agricultural methods also include low-input agriculture to decrease agriculture's energy dependence [6-8]. The 
environmental benefit of integrated agriculture is relevant in this study, while the practice to integrate crop and livestock production for the cyclical exchange of input and output is not necessarily the focus of this inquiry $[9,10]$. As such, conservation agriculture is gaining salience in policy priorities as well. As a recent example, the European Union (EU) announced the "Farm to Fork Strategy" to promote a sustainable agri-food system, which includes conservation agriculture [11]. Similarly, the Japanese government is renewing its interest in conservation agriculture through a strategy announced in May 2021 entitled "Strategy for Sustainable Food Systems" (referred hereafter as MeaDRI: Midori no Shokuryō Sisutemu Senryaku), which aims to balance economic production and environment sustainability, pursue climate change mitigation, and decrease the dependence on fossil fuels in agriculture [12]. Via this strategy, Japan aims to promote conservation agriculture as an agricultural practice from individual to community levels to counter climate change and preserve biodiversity $[5,12,13]$. The strategy promotes this type of agriculture including various numerical targets (i.e., the extent of organic agriculture to reach $25 \%$ by 2050). In this study, conservation agriculture is introduced as an agricultural practice that includes reduction of chemical pesticides and fertilizers, promotion of organic agriculture, and winter-flooded rice fields, which ultimately lead to biodiversity conservation. It is regarded as a synergistic measure with multiple benefits for climate change mitigation, water pollution, and biodiversity conservation. However, the effects of the strategy and the development of conservation agriculture are still at an early stage in Japan. Besides the national and international strategies to mitigate carbon emission, factors on the farmers side should be studied for the expansion of conservation agriculture if the strategies are to be translated into actions. The promotion of the current strategies with lofty goals demands a comprehensive quantitative study of farmers engaged in conservation agriculture as the foundation to conduct the new policies.

While the economic benefit of conservation farmers has always attracted the interest of scholars [14-16], recent studies have focused more on the social and cognitive behavioral changes in farmers who have adopted conservation agriculture [17]. Previous studies surveying farmers have mainly focused on the identification of factors that drive the adoption of methods for conservation agriculture [18-22]. According to the literature review conducted by Mozzato et al. [1], these studies initially analyzed the socio-economic variables of farmers and farm structures. They further aimed to capture the impact of behavioral factors, including social factors and attitudes such as motivation [18]. Meanwhile, the work of Bouttes et al. [13] and Dessart et al. [17] has focused more on additional behavioral factors, such as learning and the perception of cost and benefit. It is also critical to understand the satisfaction of practicing farmers at a micro level in local practices to understand the balance of environment, economy, and chemical or energy use. However, this type of study is very rare in the area of the so-called Monsson Asia, with the climate condition containing high humidity. To expand conservation agriculture in the area has been shadowed by the struggle of high cost resulting in low economic benefits.

Reflecting these previous findings, we focused more on the processes used by farmers to develop conservation agriculture. Besides the economic benefit, this study examined the factors underlying and/or related to satisfaction levels, which can further analyze the attitudinal and behavioral factors of farmers starting and continuing conservation agriculture. The study focused on the analysis of conservation farmers in Ishikawa Prefecture, Japan, especially the ones who benefited from policies on conservation agriculture. While there is undoubtedly a public interest for such practices to advance environmental and social goals, the continuity and expansion of these practices hinge on the motivations of "individual" farmers. As for the policy implications, this study aims to fill the gap among the policy's guiding principles, the farmers' motivations, and the economic influence on the ground through intensive surveys of farmers in a Japanese prefecture. In the following sections, we provide the results of review of existing studies and show the methods used, including sample size and statistical analysis. After an analysis of the results, we discuss 
the factors affecting farmers' income change and the topics related to the satisfaction of farmers, before providing a conclusion.

\section{Existing Studies on Farmers and Conservation Agriculture}

Recent studies on conservation agriculture have focused on those factors that led to the start of this agricultural practice by surveying farmers in specific locations and exploring the applicability of the results on a larger scale $[1,17,23]$. These studies analyzed factors such as the farmers' demographic characteristics, farm types, and local farm structure [1]. These become the base to predict the development of conservation agriculture [24]. One of the frontiers in this research area is the analysis of spatial attributes and interpersonal relationships, such as social capital $[1,23,25]$. The behavioral approach specifically focused on socio-psychological characteristics and learning [17]. Dessart et al. [17] classified these behavioral parameters into: (1) dispositional factors, which are stable personal characteristics (e.g., beliefs and basic preferences); (2) social factors, which are linked to social relationships (e.g., peer pressure) that affect behaviors; and (3) cognitive factors, which are concerned with learning and analysis to consider decision-making components, such as factors, results, and benefits. The systematic categorization of behavioral factors could encourage a detailed discussion and application of these factors, which are frequently interpreted as farmers' general preferences. Besides the categorical attributes of farmers and their farms, their will for social development and environmental conservation can affect the adoption of conservation agriculture [26]. In summary, the status of these personal, farm, and regional factors should be further explored to facilitate the adoption and sustenance of conservation agriculture.

Conservation agriculture has also been studied for biodiversity conservation and the enhancement of ecosystem services in addition to lower input and reduced tillage $[27,28]$. To explore the factors that facilitated the adoption of these methods and the status of the farmers, Japanese scholars have mostly conducted qualitative studies with minimal quantitative application, surveying farmers engaged in conservation and organic agriculture [29-31]. Fujita and Hatano [30] conducted a survey with comprehensive questions to capture the status of organic farmers in Japan. The study analyzed farmers' personal and family characteristics, farm types, income change, sales channels, and motivations to start organic agriculture. Similarly, Oda and Kiminami [29] surveyed farmers conducting conservation agriculture in Sado Island, Niigata Prefecture, which is a critical location for conserving the Japanese crested ibis (Nipponia nippon). Besides questions about sociodemographics, management, and the motivation explained above, they included questions about the farmers' engagement, joy of agriculture, and care for creatures. Uenishi [31] focused on the role of extension in promoting the adoption and further development of conservation agriculture by comparing two known cases in Japan: one in Sado Island and the other in Toyooka City, Hyogo Prefecture, which is known for the preservation of storks. Uenishi [31] claimed that enhancing farmers' understanding of cultivation standards, support, and marketing promoted adoption in the initial stage. Ensuring a sufficient price premium could further encourage conservation agriculture [31]. In summary, Japanese scholars have attempted to capture the adoption of conservation agriculture in cultural, environmental, and academic settings. From the empirical data, the economic benefit and satisfaction that farmers derive from conservation agricultural practices appears to be the major challenge for the adoption and development of these practices in Japan.

To date, academic discussions on farmers practicing conservation agriculture have mainly concentrated on the factors that led to the expansion of this agricultural method [18-22]. Less attention has been paid to the effects of involvement in conservation agriculture, such as income change and satisfaction. A choice of market channel can affect income [16], although farmer satisfaction has not been discussed. Alternatively, the so-called conventionalization in organic agricultural markets can lead to the marginalization of small farmers due to decreased prices and income caused by the involvement of agribusinesses and large supermarket chains of developed countries in the development of organic agriculture $[32,33]$. 
Fujita and Hatano [30] interviewed organic farmers in Japan regarding their income increase and the stability of management. They found that new farmers generally experienced income growth as, at the time of the survey, their median income had increased from a range of JPY 0.5 to 1 million to JPY 2 to 4 million from the time they started organic agriculture. Simple regression analysis found a weak correlation with years of experience. Emotional aspects, such as the joy of and care for the environment, were also covered by Oda and Kiminami [29], as mentioned earlier. Additionally, the socio-cultural situation of the development of conservation and organic agriculture has also been documented in descriptive books, including Suzuki [34] and Arai et al. [35]. Arai et al. identified limited sales channels and low income from organic agriculture as a bottleneck for Shirakawa Village, which is located in a mountainous area in Japan. Thus, the studies identifying the factors that contribute to the spread and sustenance of conservation agriculture are needed.

Along with industrialization and urbanization, agriculture and its related land use are associated with an increase in $\mathrm{CO} 2$ emissions [12,36]. Although agriculture is regarded as a contributing factor for $\mathrm{CO} 2$ emissions in developed countries [37,38], Anwar et al. [36] noted the opposite effect in developing countries and included conservation agriculture in his policy recommendations. Mitigation measures for $\mathrm{CO} 2$ emissions, which include renewable energy use, forest maintenance [36,39], and the topic of our study, conservation agriculture, are also now gaining salience.

As for farmers practicing conservation agriculture, studies have mainly focused on factors underlying the adoption of this agricultural method. In contrast, studies focusing on the effects of conservation agriculture on farmers are relatively scarce. Thus, this study focuses on the economic and behavioral effects of conservation agriculture by examining income change and satisfaction levels, among others. Although a range of items related to farmer satisfaction exists, the level of satisfaction can be further studied in relation to farm economy or efficiency [40]. The findings of this work will reinforce our understanding of practices of conservation agriculture, as well as provide policy implications from a broader perspective.

\section{Methods}

This study used a questionnaire survey of farmers. Because the prefecture provided the list of participants in relative policy schemes for the sampling frame, the results are robust enough to analyze farmers with evidence showing that they are implementing conservation agriculture in the prefecture. The response datasets were analyzed with a regression tree on income change and a multiple comparison procedure regarding their relationship with satisfaction items.

\subsection{Study Site and Sample Selection}

Our study site is Ishikawa Prefecture, which is located in the central northern part of Honshu Island. Kanazawa, the capital city, is known for its fine crafts and rich feudal history. The population of the prefecture and the city were 1.1 million and 463,583, respectively, in 2020 [41]. The number of farm managements in the prefecture was 13,636 in 2015 [42]. Farm managements cultivated 32,367 hectares, with an average size of 2.3 hectares. Traditional vegetables produced around the city and its northern region, the Noto Peninsula, are widely available in the prefecture at various venues including restaurants and morning markets [43]. The Noto Peninsula is registered as a Globally Important Agricultural Heritage System for its historically sustainable socio-ecological system of agriculture and fisheries, Satoumi and Satoyama, which are symbolized by rice terraces [44-46]. According to the 2015 Census of Agriculture and Forestry, there were 4017 conservation farmers in the prefecture, comprising $29.5 \%$ of all managements in the prefecture. This percentage is the 32nd highest in Japan [42]. However, the census data is based on the answers of individual farmers, who were not required to provide evidence to show that they were implementing conservation agriculture. Furthermore, the prefecture has also displayed promising trends in conservation agriculture. The share of organic dry fields of the prefecture's total amount 
of dry fields was $3.0 \%$ in 2018, the highest in Japan [47]. With such relative advantages of conservation agriculture within past and recent agricultural development in the area, this study can contribute to the development of conservation agriculture at the regional and national levels.

This study initially identified potential respondents through comprehensive documents retrieved from Ishikawa Prefecture's official bodies that list those farmers who are beneficiaries of conservation agriculture policies. To receive the subsidies attached to the policies, farmers need to submit evidence to verify their practice of conservation agriculture. These policies include: Specially Cultivated Agricultural Products (Tokubetsu Saibai in Japanese), Direct Payment for Conservation Oriented Agriculture, JAS (Japanese Agricultural Standards) Organic Standards certified by the prefecture, and Ikimono Genki Mai Ninsho (Certificate of Rice with Active Creatures). The four policies have 38, 98, 19, and 9 people or entities involved, respectively. Because farmers can form a group to apply for a policy and obtain certificates, all names on the lists may not clearly indicate whether they represent an individual farmer, a farmer group, or a corporate. As respondents from farmer groups and corporations basically represent an opinion of their organizations, this study regarded all respondents as individual farmers. The study assumes a respondent reflects the general characteristics and opinions of the group to answer the questionnaire.

After correcting the overlaps of farmers registering for multiple schemes and removing the farmers whose addresses were not on the beneficiary conservation farmers list, the names and addresses of 73 farmers practicing conservation agriculture in Ishikawa Prefecture were identified. In August 2020, we mailed each a questionnaire, clearly stating the research purpose while highlighting the voluntariness of participation. A total of 51 responses were collected before the December 2020 deadline, with 44 responses containing complete attributes to conduct statistical inference between income change and the items on satisfaction through conservation agriculture. Additionally, we interviewed three farmers by telephone in order to understand the reasons for their answers on their satisfaction with direct payment policies.

In this way, the study obtained a sampling frame of 73 conservation farmers. It assumed these farmers consisted of the population of conservation farmers in Ishikawa Prefecture. Their practice is rather certain as they can provide evidence of conservation agriculture. They are also suitable to analyze and discuss the adoption of policies to promote conservation agriculture. The sampling frame was possibly the best in practice to represent conservation farmers in Ishikawa Prefecture to discuss policy promotion. Furthermore, 44 responses were above the appropriate sample size of 40.70 calculated using Cochran's formula [48,49]. The calculation was performed using a confidence level of $95 \%$ and sampling error of $10 \%$. The response rate to answer both the question on income change and those on satisfaction was derived from $44 / 73$ (about 0.603 ). The population size for the analysis was 73 .

\subsection{Survey Questionnaire}

The questionnaire used in this study included questions on the profiles and characteristics of the farmers, agricultural types, practices of conservation agriculture, sales and income, certificate types, motivations to start and satisfaction achieved through conservation agriculture, and satisfaction with policies at different times (Table 1).

\subsubsection{Sales Channels and Income Change}

Farmers were asked whether there were any changes in their sales channels before and after they started conservation agriculture. The choice of sales channels included: (1) direct consumer sales; (2) direct sales stores; (3) schools; (4) agricultural cooperatives; (5) consumer cooperatives; (6) processors; (7) wholesalers, except for agricultural and consumer cooperatives; (8) retail shops; (9) restaurants; (10) internet sales; and (11) others. Direct sales stores usually sell the products that a farmer supplies in person. The stores can be owned by local governments, agricultural cooperatives, or farmers themselves. These options 
were based on items listed in Fujita and Hatano [30] and MAFF [50] to reflect the situation of the agricultural and food markets in Japan and to enable comparisons. If many farmers chose retail shops as a sales channel and showed a low level of income increase, it would indicate that the market and distribution could be affected by conventionalization [32,33]. A high level of market intrusion can thus marginalize the production of small farmers and decrease their income.

Table 1. Ishikawa Prefecture conservation agriculture questionnaire items.

\begin{tabular}{|c|c|c|}
\hline Category & Item & Answer Method \\
\hline \multirow{3}{*}{ Individual } & Age & Years \\
\hline & $\begin{array}{c}\text { Years of practicing } \\
\text { conservation agriculture }\end{array}$ & Years \\
\hline & Prospect of a successor & Multiple choice \\
\hline \multirow[t]{2}{*}{ Agriculture } & $\begin{array}{l}\text { Five best-sold crops and the sizes } \\
\text { of the area on which each crop } \\
\text { is produced }\end{array}$ & $\begin{array}{l}\text { Crop name and land area } \\
\text { by hectare }\end{array}$ \\
\hline & $\begin{array}{c}\text { Practices of } \\
\text { conservation agriculture }\end{array}$ & Multiple answers possible \\
\hline \multirow{4}{*}{ Sales and income } & Annual sales & JPY 10,000 \\
\hline & $\begin{array}{l}\text { Sales channels before starting } \\
\text { conservation agriculture }\end{array}$ & Multiple answers possible \\
\hline & $\begin{array}{l}\text { Sales channels after starting } \\
\text { conservation agriculture }\end{array}$ & Multiple answers possible \\
\hline & $\begin{array}{c}\text { Income change with conservation } \\
\text { agriculture on land with } \\
\text { certification and } \\
\text { without certification }\end{array}$ & Multiple choice \\
\hline Certification & Certificate type & Multiple answers possible \\
\hline Motivation & $\begin{array}{c}\text { Motivation to start } \\
\text { conservation agriculture }\end{array}$ & $\begin{array}{l}\text { List three items in order } \\
\text { of relevance }\end{array}$ \\
\hline Satisfaction & $\begin{array}{c}\text { Satisfaction from } \\
\text { conservation agriculture }\end{array}$ & $\begin{array}{l}\text { For each item, a five-point scale } \\
\text { ranging from very satisfied, } \\
\text { satisfied, neither satisfied nor } \\
\text { dissatisfied, somewhat } \\
\text { dissatisfied, to dissatisfied }\end{array}$ \\
\hline Policy & $\begin{array}{l}\text { Satisfaction with policy at } \\
\text { different times }\end{array}$ & $\begin{array}{l}\text { For policy, a scale ranging from } \\
\text { very satisfied to dissatisfied. } \\
\text { Satisfaction in Year } 1 \text { and Year } 4 \text { or } \\
\text { longer in conservation agriculture }\end{array}$ \\
\hline
\end{tabular}

Income changes were classified as slight or large changes (increase or decrease). The intervals for increase were less than $5 \%, 5 \%$ to less than $10 \%, 10 \%$ to less than $15 \%$, and $15 \%$ or more. The intervals for decrease were less than $10 \%, 10 \%$ to less than $20 \%, 20 \%$ to less than $30 \%, 30 \%$ to less than $50 \%$, and $50 \%$ or more. To analyze the causes and effects of income change, the intervals were simplified to increase, same, and decrease, which were denoted as 1,0 , and -1 , respectively.

\subsubsection{Certification}

We covered the types of certificates that these farmers possess. These included Rice with Active Creatures, which is a certificate for specially cultivated agricultural products, JAS Organic Standards, Good Agricultural Practice (GAP), Hazard Analysis Critical Control Point (HACCP), Geographical Indications (GI), and Regional Collective Trademark (RCT). A farmer qualifies for a certificate for specially cultivated agricultural products if 
they decrease the frequency of applying certain chemicals to $50 \%$ or less compared with conventional agriculture and the nitrogen content of chemical fertilizers to $50 \%$ or less [51]. GAP certifies a farmer for sustainable attempts in production processes [52]. HACCP is a guideline for hygiene control in the handling of food [53]. GI registers locally or regionally unique products for intellectual property protection [52]. The RCT system allows the registration of trademarks linking a place name and a general commodity or service name [54].

\subsubsection{Motivation to Start Conservation Agriculture}

Farmers were asked to rank three items from a given list (adopted from Fujita and Hatano [30]) that would best describe their motivations to start conservation agriculture. The list included: (1) production of safe and secure foods; (2) production of high-quality foods; (3) interest in environmental protection and biodiversity; (4) disliking pesticides; (5) recommendation or advice from other practitioners; (6) inspiration from books, magazines, TV, or radio; (7) taking over a parent's agricultural methods; and (8) others.

\subsubsection{Satisfaction from Conservation Agriculture}

Farmers were asked about the satisfaction level for multiple aspects of conservation agriculture. The farmers' choices ranged from 5-very satisfied to 1-dissatisfied. Satisfaction levels were asked in relation to: (1) production of safe and secure foods; (2) production of high-quality foods; (3) protection of the environment and biodiversity; (4) fellowship with farmers practicing conservation agriculture; (5) interest and ambition in agriculture and agricultural methods; and (6) family relationship. The first three items were adjusted to correspond with the items provided in the motivation question.

\subsubsection{Satisfaction with Policy at Different Times}

We further analyzed farmers' satisfaction with three different supporting schemes at different periods (first to fourth year after the introduction of conservation agriculture). Farmers were asked to choose a level of satisfaction with each policy across each year of conservation agriculture. Their level of satisfaction was chosen based on a five-point scale: 1-dissatisfied to 5-very satisfied. Three direct payment schemes were involved, namely the Multifunctional Payment, which supports cooperative activities contributing to multifunctionality [5]; Direct Payment for Hilly and Mountainous Area, which attempts to pay the cost difference between the maintenance of a flat agricultural environment and a mountainous environment [5,55]; and Direct Payment for Conservation Oriented Agriculture, which supports farmers with the cost increase associated with agricultural activities that contribute to the protection of the environment [5].

\subsection{Quantitative Analysis Methods}

\subsubsection{Regression Tree}

This study estimated the factors affecting income change using a regression tree. The dependent variable was income increase, income decrease, or no change. The independent variables included farmers' individual information, the information on agriculture (including the practice of rice agriculture and the practices of conservation agriculture), annual sales, marketing channels before and after starting conservation agriculture, and whether they had a certification.

To identify the key factors, a regression tree calculates the entropy for each independent variable. The smallest entropy determines the value of a certain variable as a threshold to divide the samples. The calculation continues until the comparison to find a smaller entropy ends. Limiting the number of iterations to decide a threshold could simplify a tree. In the same way, the Gini impurity could decide the threshold. 


\subsubsection{Bonferroni Adjustment}

This study conducted a multiple comparison procedure on three average scores of a satisfaction item. The respondents were divided into three groups based on the difference in income change: increase, same, and decrease. This enabled the study to conduct a statistical test on the three average values of the groups for each item of the satisfaction question.

The test included a Bonferroni adjustment to avoid a Type 1 error resulting from multiple testing. A Bonferroni adjustment lowers an evaluation criterion by dividing it by the number of tests. Compared with other statistical methods, a Bonferroni adjustment was appropriate in this study because the number of respondents in a divided group was too small to evaluate whether these samples followed a normal distribution and whether the population variances of the divided groups were equal. The test was performed using SPSS 27.

\section{Results}

\subsection{Characteristics of Farmers and Their Conservation Agriculture}

The majority of farmers in this study were more than 50 years old $(76.5 \%$ of 51 valid answers), with an average age of 60.5. The average number of workers on a farm was 7.2, although this value might reflect the existence of the farmer groups for policy or certification purposes (50 valid answers). There were 28 farmers (57.1\%) who indicated some prospect of a successor ( 49 valid answers). Of the five crops with the highest sales, rice was the dominant crop, as indicated by $37(77.0 \%)$ farmers. The majority of farmers were engaged in rice agriculture ( $83.3 \%$ of 48 valid answers). The average number of years practicing conservation agriculture was 14.7 (48 valid answers). A total of $28(58.3 \%)$ of farmers had been practicing it for more than 10 years ( 48 valid answers). The average length of time was 14.7 years.

According to the results of the question on practices of conservation agriculture, farmers were more likely to apply these methods to reduce chemical use than for habitat preservation. The three largest values for selected choices were related to the use of agricultural chemicals ( $72 \%$ for item (1), $46 \%$ for (2), and $42 \%$ for (3), among 50 valid responses in Table 2). Just over a third of farmers were certified organic (34\%). The choices of methods of conservation agriculture with the three smallest values were related to habitat preservation (20\% for item (8), $12 \%$ for (9), and $0 \%$ for (10)).

Table 2. Practicing methods of conservation agriculture ( $n=50$, multiple answers possible).

(1) Reducing chemical fertilizer and chemically synthesized fertilizer to less than a half of those for conventional agriculture

(2) No application of herbicide over ridges between farmland plots

(3) No application of systematic insecticide such as neonicotinoid pesticides

\section{$46 \%$}

(4) Organic certified with JAS

(5) Practicing a winter-flooded rice field

\section{$42 \%$}

$34 \%$

(6) Applying neither chemical fertilizer nor chemically synthesized

$24 \%$ pesticide without a JAS certificate

(7) Rationalizing land use of conservation agriculture in neighboring fields

$22 \%$

(8) Leaving the edge of rice fields as a swale

$20 \%$

(9) Creating a biotope on an uncultivated rice field

(10) Installing a fish waterway

(11) Other methods

\subsubsection{Motivation to Start Conservation Agriculture}

The three main motivation types to start conservation agriculture were the production of safe and secure foods, the production of high-quality foods, and interest in environmental conservation and biodiversity $(80.9 \%, 68.1 \%$, and $59.6 \%$, respectively, with 47 valid respondents; Figure 1). However, few farmers indicated an interest in environmental protection and biodiversity as their single most important motivation (4.3\%). 


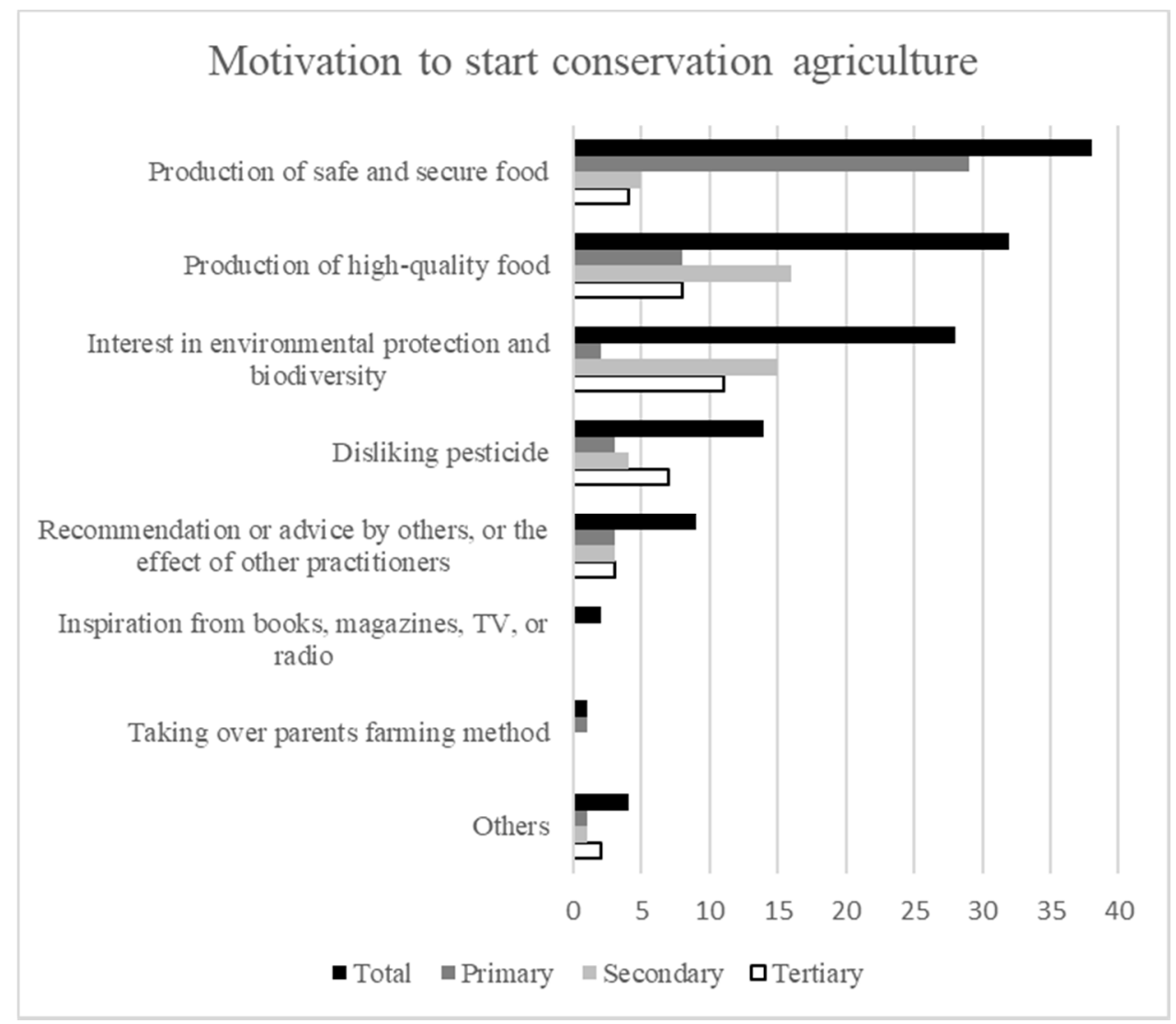

Figure 1. Ishikawa Prefecture farmers' motivation to start conservation agriculture $(n=47)$.

\subsubsection{Sales and Sales Channels}

The mean of farmers' annual sales was JPY 32.8 million and the median was JPY 9 million (49 valid answers). About half of the farmers had sales exceeding JPY 10 million $(49.0 \%)$. A major sales channel was direct consumer sales (78.0\% of 50 valid respondents), with the second-largest proportion being direct sales stores (42.0\%). Certain farmers also sold their products to wholesalers, agricultural cooperatives, restaurants, and retail shops $(40.0 \%, 36.0 \%, 32.0 \%$, and $26.0 \%$, respectively). They also made internet sales $(26.0 \%)$.

Compared with before practicing conservation agriculture, farmers increased the number of sales channels from 2.3 to 3.1 on average ( 49 valid respondents). About half of the farmers increased their number of sales channel types ( $54.2 \%)$, while a few experienced a decrease $(10.4 \%)$. More farmers traded with restaurants, direct consumer sales, wholesalers, retail shops, and made internet sales $(19.8 \%, 18.9 \%, 13.5 \%, 11.8 \%$, and $11.7 \%$ increase, respectively). Although the decrease was small, fewer farmers traded with agricultural cooperatives and consumer coops (6.9\% and $4.2 \%$ decrease, respectively).

\subsubsection{Certificates}

More than half of the farmers earned certification for specially cultivated agricultural products (56.9\% of 51 respondents). As mentioned above, 33.3\% of the farmers were certified as organic under the JAS Organic Standards. The same proportion was certified with GAP (33.3\%).

\subsection{Factors That Affect Income Increase}

This study separated the question about income change into two agricultural situations: one with a certification and the other without any certification. Four farmers provided the same responses in these two situations, while three answered differently. This study took account of answers in each category. Of the 44 responses with the complete attributes for a series of the analyses in this study, 22 experienced an income increase, 12 an income 
decrease, and 20 were neutral. The study generated a regression tree to analyze the factors of income increase among the farmers (Figure 2). The results showed that years of experience, trade with a retail shop, and age tended to cause an income increase. If a farmer had been engaged in conservation agriculture for fewer than six years, income tended to decrease. If they had been doing so for six or more years, their income tended to increase. Furthermore, among the farmers who neither engaged in conservation agriculture for fewer than six years nor traded with a retail shop to sell their products, those who were 62 years old or older tended to increase their income. Conversely, those under 62 years old were less likely to increase their income under the same conditions. Selling conservation agriculture products in retail shops is relatively new in Japan, and elderly farmers might not need to adapt to it very much to increase their income.

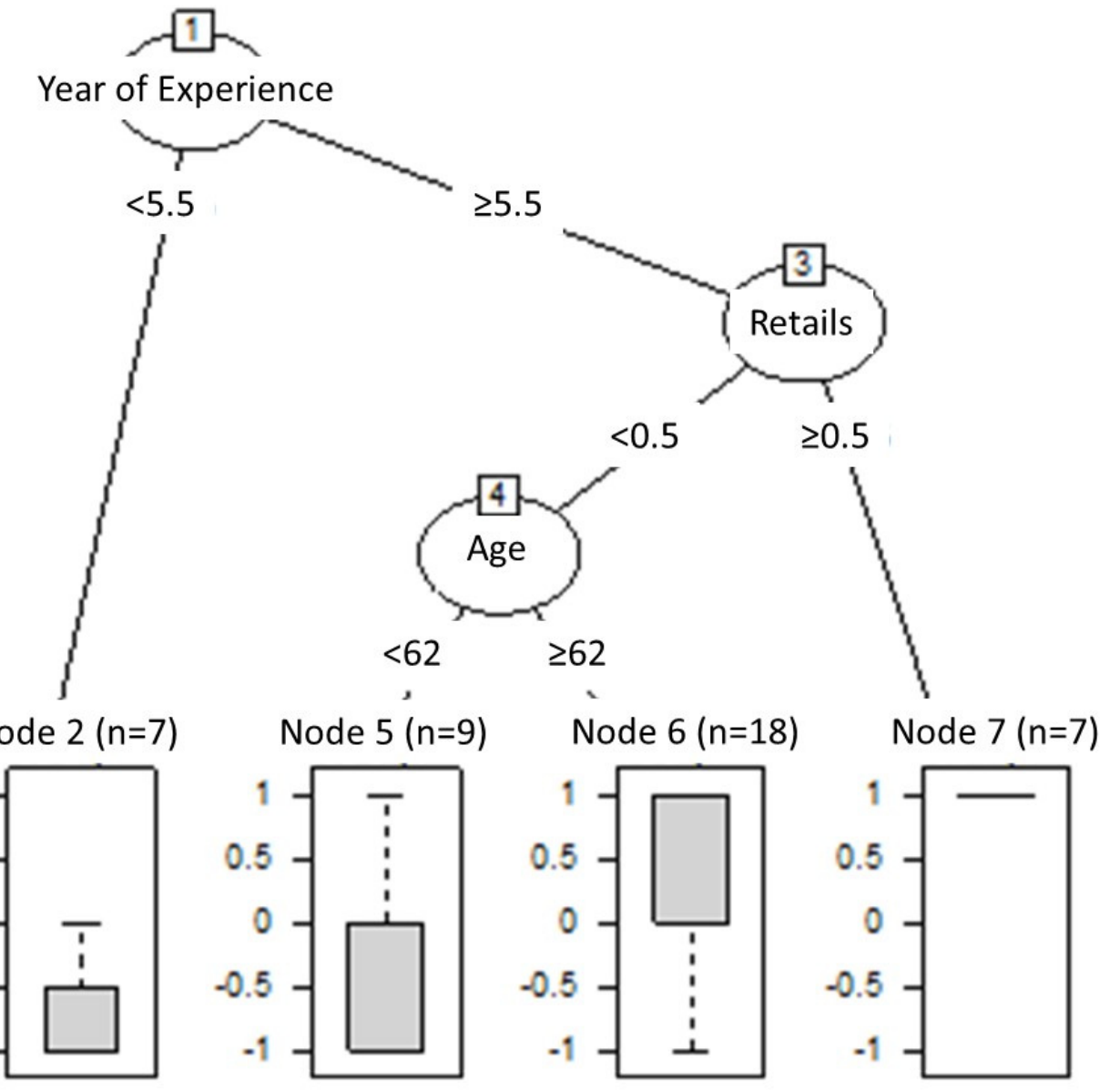

Figure 2. Regression tree of income increase among farmers practicing conservation agriculture. (Note: The nodes of years of experience, age, and retail indicate the number of years of conducting conservation agriculture, age of farmers, and trade with a retail shop where farmers sell their products, respectively).

\subsection{Satisfaction from Conservation Agriculture}

Satisfaction from conservation agriculture was first calculated and summarized by combining the five possible answers into the following three groups: (1) satisfied or very satisfied; (2) neither satisfied nor dissatisfied; and (3) somewhat satisfied or dissatisfied (Figure 3). Many farmers are satisfied or very satisfied with the production of safe and secure food, protection of the environment and biodiversity, and production of high-quality foods $(86.7 \%, 80.4 \%$, and $78.3 \%$, respectively). On the contrary, the item with the lowest level of satisfaction was fellowship with farmers practicing conservation agriculture (only $39.1 \%$ were satisfied or very satisfied). 


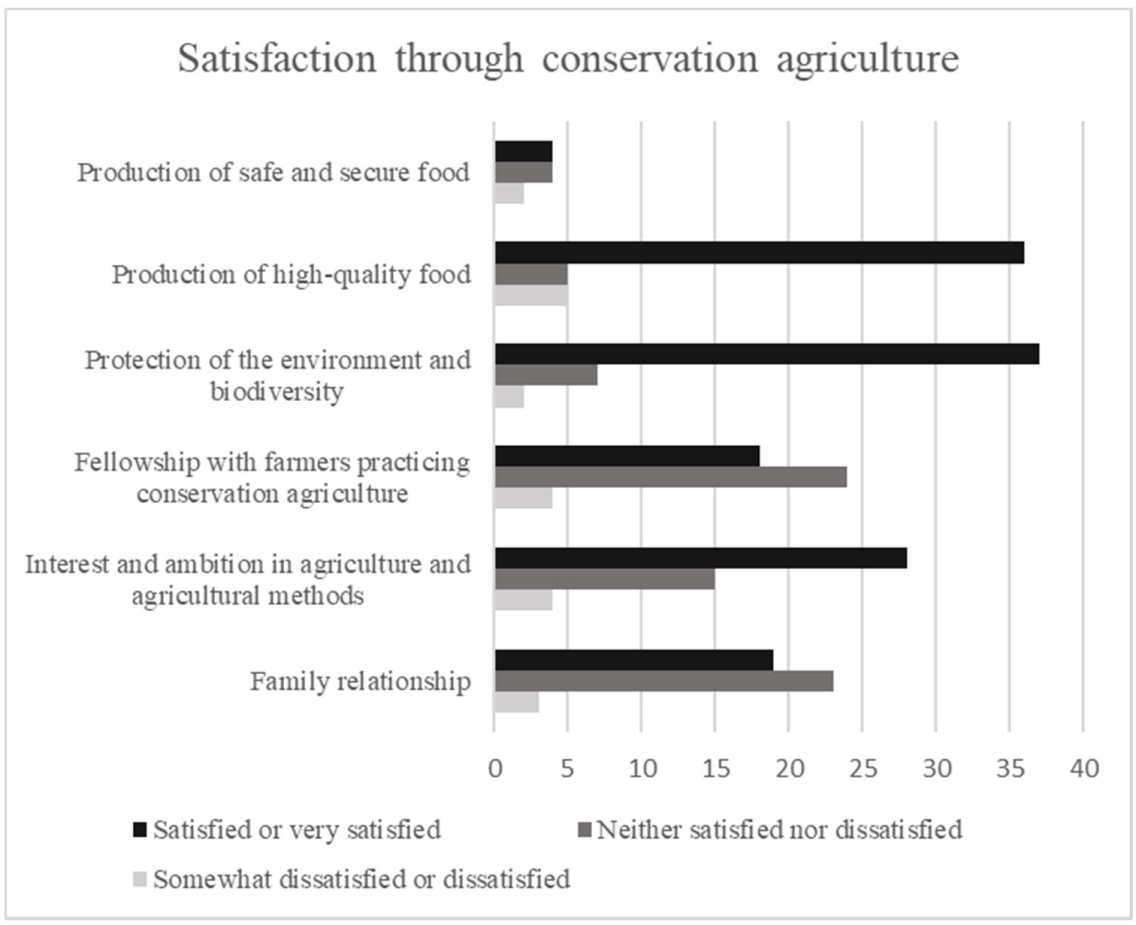

Figure 3. Ishikawa Prefecture farmers' satisfaction through conservation agriculture.

Additionally, Figure 4 shows the average scores of farmers' satisfaction according to income change: increase, same, and decrease (excluding those responses of farmers answering differently about income change versus the existence of certification). The average satisfaction with income increase was the largest for all items. Four items had an average satisfaction increase as income increased: production of high-quality foods, fellowship with farmers practicing conservation agriculture, interest and ambition in agriculture and agricultural methods, and family relationships. On the other hand, farmers who had the same level of income were the least satisfied with the production of safe and secure foods and protection of the environment and biodiversity.

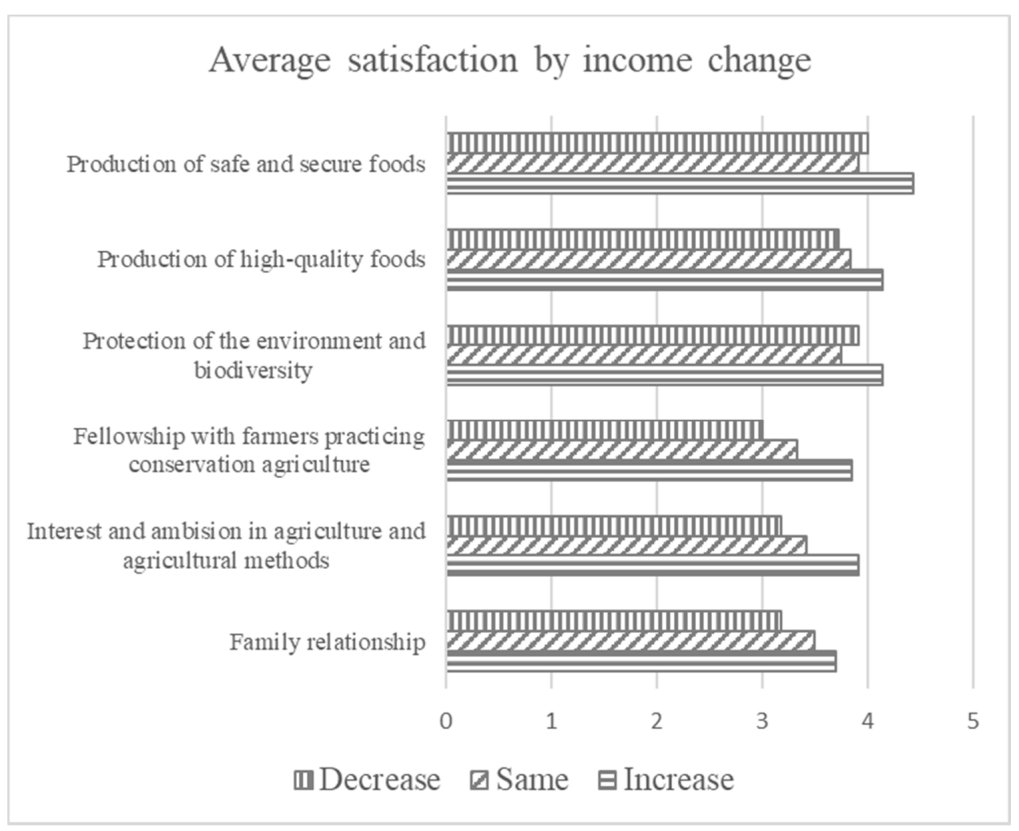

Figure 4. Average satisfaction of farmers practicing conservation agriculture by income change. 
Table 3 shows the primary motivations to start conservation agriculture and the average score of the corresponding satisfaction items. This could indicate that some initial motivations were more likely to be rewarding. The motivation to produce high-quality foods resulted in a high level of satisfaction (4.5). Two other motivations that resulted in a high level of satisfaction were the production of safe and secure foods (4.25) and the recommendation or advice of others, or the effect of other practitioners (4). The latter item corresponded to fellowship with farmers practicing conservation agriculture. Interest in environmental protection and biodiversity and taking over a parent's agricultural method had low initial motivation levels ( 2 and 1 farmers, respectively), while the average levels of satisfaction were neutral (both 3).

Table 3. Ishikawa Prefecture farmers' initial motivation and current satisfaction.

\begin{tabular}{|c|c|c|}
\hline Motivation & Number of Farmers & $\begin{array}{c}\text { Average Scores in } \\
\text { Corresponding Satisfaction }\end{array}$ \\
\hline Production of safe and secure foods & 31 & 4.25 \\
\hline Production of high-quality foods & 6 & 4.5 \\
\hline $\begin{array}{l}\text { Interest in environmental protection } \\
\text { and biodiversity }\end{array}$ & 2 & 3 \\
\hline $\begin{array}{l}\text { Recommendation or advice by others, } \\
\text { or the effect of other practitioners }\end{array}$ & 3 & 4 \\
\hline Books, magazines, $\mathrm{TV}$, or radio & 0 & $\mathrm{n} / \mathrm{a}$ \\
\hline $\begin{array}{l}\text { Taking over parents' } \\
\text { agricultural method }\end{array}$ & 1 & 3 \\
\hline
\end{tabular}

Based on the result of multiple comparison of the averages of satisfaction level of income-change groups, Table 4 shows the result of a test with a Bonferroni adjustment. It indicates that the average satisfaction in fellowship with farmers practicing conservation agriculture was significantly different between the farmers with an income increase and those with an income decrease $(p<0.05)$ (Table 4$)$. The result suggests that income change was related to satisfaction in the relationships with other farmers interested in biodiversity conservation measures.

Table 4. Results of multiple comparison procedure with a Bonferroni adjustment.

\begin{tabular}{|c|c|c|c|c|c|c|}
\hline \multirow{2}{*}{ Variable } & \multirow{2}{*}{ Group } & \multirow{2}{*}{ Mean Difference } & \multirow{2}{*}{ Standard Error } & \multirow{2}{*}{$p$ Value } & \multicolumn{2}{|c|}{$95 \%$ CI of the Difference } \\
\hline & & & & & Lower & Upper \\
\hline $\begin{array}{l}\text { Level of satisfaction in } \\
\text { fellowship with farmers } \\
\text { practicing conservation } \\
\text { agriculture (1-5) }\end{array}$ & $\begin{array}{l}\text { Income increase } \\
\text { Income decrease }\end{array}$ & -0.857 * & 0.335 & 0.043 & -1.693 & -0.020 \\
\hline
\end{tabular}

Note: * The mean difference is significant at the 0.05 level.

\subsection{Satisfaction with Payment Policies}

This study asked about satisfaction with three types of direct payment schemes in Japan: Multifunctional Payment, Direct Payment for Hilly and Mountainous Area, and Direct Payment for Conservation Oriented Agriculture. The first two payment types satisfied more farmers though most were not dissatisfied. Regarding Direct Payment for Conservation Oriented Agriculture, more farmers were dissatisfied than farmers evaluating the other subsidy schemes, whether they were in their initial year or had been practicing conservation agriculture for four or more years. Dissatisfaction could decrease as farmers practice conservation agriculture for many years.

\subsubsection{Multifunctional Payment}

Of the 20 farmers who answered the question about satisfaction with Multifunctional Payment in their first year of conservation agriculture, $9(45 \%)$ were satisfied, $6(30 \%)$ 
were dissatisfied, and $5(22.7 \%)$ were neutral. Of the 22 farmers who had been practicing conservation agriculture for four or more years, 12 (54.4\%) were satisfied, $5(22.7 \%)$ were dissatisfied, and $5(22.7 \%)$ were neutral.

\subsubsection{Direct Payment for Hilly and Mountainous Area}

Of the 17 farmers who answered the question about satisfaction with Direct Payment for Hilly and Mountainous Area in their first year of conservation agriculture, 7 (41.2\%) were satisfied, 5 (29.4\%) were dissatisfied, and $5(29.4 \%)$ were neutral. Of the 18 farmers who had been practicing conservation agriculture for four years or longer, $9(50.0 \%)$ were satisfied, 4 (22.2\%) were dissatisfied, and 5 (27.8\%) were neutral.

\subsubsection{Direct Payment for Conservation-Oriented Agriculture}

Of the 23 respondents who answered the question about their satisfaction with Direct Payment for Conservation Oriented Agriculture in their first year of conservation agriculture, 7 (30.4\%) were satisfied, 11 (47.8\%) dissatisfied, and 5 (21.7\%) neutral. Of the 24 participants who had been practicing conservation agriculture for four years or longer, $8(33.3 \%)$ were satisfied, $9(37.5 \%)$ were dissatisfied, and $7(29.2 \%)$ were neutral.

\section{Discussion}

\subsection{Factors Affecting Income Change}

Years of experience, trade with a retail shop, and age can affect income change. Although Fujita and Hatano [30] documented a weak correlation between income increase and years of experience among new organic farmers in Japan, the findings of the current study provide a more in-depth understanding of how income increases in conservation agriculture. For instance, years of experience and age significantly affected income change; as the number of years increases, agricultural skills become more enhanced and the production more stabilized. Additionally, this study documented that trade with a retail shop would increase income, which is similar to the findings of Pham and Shively [16], who noted that market channel types can affect income. Although farmers in conservation agriculture may have several types of sales channels, the results showed that retail shops are the most effective channels for increasing income, particularly for younger farmers in conservation agriculture. One possible explanation is that farmers stand a better chance of increasing their income as retail industries become more interested in the products of conservation agriculture, especially organic products. Additionally, further development of the tea export market from conservation and organic production stimulates the conversion of tea producers [56]. Elderly farmers can increase their income by using more traditional sales channels for conservation agriculture, such as direct consumer sales and consumer cooperatives. By doing so, the available sales channels will change and farmers will have more time to adapt to these changes based on their respective ages. The dependency on retail industries to develop a conservation farm sector can be regarded as a sign of conventionalization, even though the concept was originally applied to organic agriculture $[32,33,57]$. According to studies on the political ecology of organic agriculture in California, exposure to market rule placed pressure on small organic farms and allowed the prioritization of large, specialized farms [32,33]. This phenomenon also lowered the interest in environmental protection among new farmers according to a study of German farmers [57]. Additionally, Oda and Kiminami [29] discussed the fact that elderly farmers were more interested in the environment than younger farmers, who tended to be more interested in subsidies. Oda and Kiminami [29] further highlighted that the feeling agriculture is a worthwhile pursuit can alleviate this issue. Resisting alienation by conventionalization could be a key when critical discourse is taken into consideration [58]. Fujita and Hatano [30] mentioned that organic farmers in Japan were less capable of negotiating prices with agricultural and consumer cooperatives than wholesalers. To lessen the negative effects of conventionalization in Japan, existing cooperative sales channels with a long 
supply chain might need to review their purchase and sales planning toward a shorter and more sustainable supply chain.

\subsection{Characteristics of Satisfaction}

This analysis showed that the enhancement of satisfaction by conservation agriculture was asymmetric through time. Most farmers surveyed were satisfied with personal and environmental attributes of motivations: the production of safe and secure food, protection of the environment and biodiversity, and production of high-quality food, which is similar to the findings of Mozzato et al. [1] and Morel and Léger [26]. The items of safe, secure, and high-quality food should be rewarding to pursue as a majority of farmers chose these personal attributes as motivations. The satisfaction that results from producing high-quality food demands more consideration as it was not observed in a previous study on barley production [59]. At the same time, farmers might not be completely sure about which motivations had to be fulfilled or were worth exploring when they started conservation agriculture. In this sense, motivation and satisfaction demonstrate time differentiation. A comparison of the various motivation and satisfaction items showed that environmental attributes could surpass personal attributes. The protection of the environment and biodiversity eventually surpassed the production of high-quality foods. The protection of biodiversity including bees $[60,61]$ and surrounding forest [62] may further the satisfaction. In the same way, interest and ambition in agriculture and agricultural methods might satisfy farmers who tend not to periodize them at an initial stage. A social factor, namely fellowship with farmers practicing conservation agriculture, might not be as satisfying as other items of satisfaction. This reflects that those organic farmers and farmers who reject chemical use are mainly in the minority. Practicing farmers tend to feel estranged or distance themselves from neighboring farmers during the initial period [30]. Although this feeling of loneliness subsides after a continued period, fellowship has the potential to be effective for increasing income. This issue demands more practical and academic attention.

\subsection{Relation with Satisfaction}

Furthermore, this study also showed that farmers' satisfaction could be related to other variables. Intensive information sharing is the key to improving the practice of conservation agriculture [63]. This study distilled the relationship between income change and social relations among farmers engaged in conservation agriculture. Referring to both motivation and satisfaction at the appropriate time can promote a balanced development of farmers. Our results indicated that more studies are required to understand both the characteristics of satisfaction and how they interact with interpersonal relationships for extracting the benefits of social factors on farm management. Farmers can share information to stabilize production in the same area and to manage better [2,17]. Farmers can effectively improve their costly or depleting processes when they have the information to compare their processes with those of nearby farmers [64]. Simultaneously, social factors might not work well in certain situations. Farmers might simply have no fellow farmers near them [17]. The differences in technologies, applications, and perceptions of agriculture and nature could potentially prevent them from networking with other farmers. Thus, a sensitive approach is required to evaluate whether a relationship with satisfaction is theoretical or practical.

\section{Conclusions}

This study gained unique insights into conservation agriculture, especially dynamic characters on perceptions of agricultural practice and the policy of farmers at the regional level. In summary, the study examined the effects of conservation agriculture on farmers (including factors influencing satisfaction) that contribute to the understanding of both the economic and behavioral factors affecting this practice. This study identified the relationship among income change, years of experience, trade with retail shops, and age. The relationship between income change and satisfaction with the farmer's social network 
was also identified. Because the level of satisfaction with the social network was lower than the other categories in this study, the promotion of the network is likely to be laborious. In addition, through discussions about the relationship between motivation and satisfaction, this study can infer that the development of conservation agriculture is dependent on the contexts of time and space, and careful considerations are necessary. Compared with the level of motivation on environmental protection, the satisfaction level grew through the years. Income changes can also reflect the changing market situation for organic agricultural products in Japan.

There are policy implications in three relevant domains, namely the change of sales channels, the inclusion of satisfaction, and networking policies, especially to improve farmers' income. First, this study identified that trade with a retail shop is a significant factor that increases income despite the concerns over the introduction of large retail industries in organic agricultural products [57]. Through the result of this study, the establishment of fairer transactions is more likely to happen with the introduction of retail industries in the sector. This possibility should be more certain when the government cooperates with farmers to calculate the cost gap between conventional and conservation agriculture. This will also reduce complaints about the direct payment scheme.

Next, the significant relationship between increasing income and the satisfaction with peer conservation that farmers observed in this study implies the potential for the government to apply network policies. With the ultimate goal of increased income, the application of network policies can help improve farmers' knowledge and facilitate information exchange among them and other stakeholders in the context of conservation agriculture $[65,66]$. Simultaneously, this study found that farmers tended to have difficulty in recognizing their satisfaction with networking. The government or other supporting agencies should provide well-coordinated networking among farmers.

Studies related to the satisfaction of farmers are still in the exploratory phase. Thus, further studies can explore the time- and space-specific characteristics of satisfaction and contribute to the development of conservation agriculture at both the initial and subsequent stages. The trend of satisfaction and income change in this study is focused on conservation agriculture in Ishikawa Prefecture. Future studies will examine this tendency in other Japanese regions. The result of this study will then be investigated in a relatively similar agronomical context with different policy promotion; for example, Taiwan and South Korea. South Korea conducts an extensive public procurement program to promote conservation and organic agriculture [67]. Furthermore, this study only focused on open-field agriculture. Future studies can target additional types of agriculture such as sustainable greenhouse agriculture, which is also a policy target in MeaDRI [12]. Additionally, knowledge transmission is also an issue to be examined in future studies [68,69]. Future international studies about knowledge transmission to promote conservation agriculture can help improve the balance between economic sustainability and environmental conservation. To understand the benefits and disadvantages of changes in the agricultural market, the historical context of organic and conservation agriculture needs to be considered (cf. [70]).

Author Contributions: Conceptualization, S.K., Y.M., Y.U. and R.K.; methodology, Y.M., S.K., Y.U. and R.K.; software, Y.M. and S.K.; validation, Y.M., S.K., Y.U. and R.K.; formal analysis, Y.M., S.K., Y.U. and R.K.; investigation, Y.M., S.K., Y.U. and R.K.; resources, R.K., S.K., Y.U. and Y.M.; data curation, Y.M., S.K., Y.U. and R.K.; writing-original draft preparation, Y.M., S.K., Y.U. and R.K.; writingreview and editing, Y.M., R.K., Y.U. and S.K.; visualization, Y.M., S.K., Y.U. and R.K.; supervision, R.K. and Y.U.; project administration, R.K., Y.U., Y.M. and S.K.; funding acquisition, R.K. All authors have read and agreed to the published version of the manuscript.

Funding: The study for this article was funded by Policy Research Institute MAFF of Japan as a Commissioned Project for the Policy Science of Agriculture, Forestry, and Fisheries between 2018 and 2020: Factors to Facilitate Production and Export of Organic Agricultural Products: Analysis of Status and Trends in EU and Implications for Japan. The JSPS KAKENHI Grant Numbers were JP16KK0053, JP17K02105, JP20K12398, and JP21K18456. Additionally, the study was supported by JST RISTEX Grant Number JPMJRX20B3, Japan, and JST Grant Number JPMJPF2110. 
Institutional Review Board Statement: This study regarded and consulted the rules involving human subjects for research in the institutions of the authors.

Informed Consent Statement: Informed consent was obtained from all subjects involved in the study.

Data Availability Statement: Any request for the data of this study will be considered.

Conflicts of Interest: The authors declare no conflict of interest.

\section{References}

1. Mozzato, D.; Gatto, P.; Defrancesco, E.; Bortolini, L.; Pirotti, F.; Pisani, E.; Sartori, L. The role of factors affecting the adoption of environmentally friendly farming practices: Can geographical context and time explain the differences emerging from literature? Sustainability 2018, 10, 3101. [CrossRef]

2. Wezel, A.; Brives, H.; Casagrande, M.; Clement, C.; Dufour, A.; Vandenbroucke, P. Agroecology territories: Places for sustainable agricultural and food systems and biodiversity conservation. Agroecol. Sustain. Food 2016, 40, 132-144. [CrossRef]

3. McGranahan, D.A. Ecologies of scale: Multifunctionality connects conservation and agriculture across fields, farms, and landscapes. Land 2014, 3, 739-769. [CrossRef]

4. Food and Agriculture Organization of the United Nations. Conservation Agriculture. 2022. Available online: https://www.fao. org/conservation-agriculture/en/ (accessed on 1 February 2022).

5. Ministry of Agriculture, Forestry and Fisheries (MAFF). About Direct Payment for Conservation Oriented Agriculture; Ministry of Agriculture, Forestry and Fisheries: Tokyo, Japan, 2020. (In Japanese)

6. Atlin, G.N.; Frey, K.J. Breeding crop varieties for low-input agriculture. Am. J. Altern. Agric. 1989, 4, 53-58. [CrossRef]

7. Schaller, N. Mainstreaming low-input agriculture. J. Soil Water Conserv. 1990, 45, 9-12.

8. Fess, T.L.; Kotcon, J.B.; Benedito, V.A. Crop Breeding for low input agriculture: A sustainable response to feed a growing world population. Sustainability 2011, 3, 1742-1772. [CrossRef]

9. Liebig, M.A.; Herrick, J.E.; Archer, D.W.; Dobrowolski, J.; Duiker, S.W.; Franzluebbers, A.J.; Hendrickson, J.R.; Mitchell, R.; Mohamed, A.; Russell, J. Aligning land use with land potential: The role of integrated agriculture. Agric. Environ. Lett. 2017, 2, 170007. [CrossRef]

10. Hendrickson, J.R.; Hanson, J.D.; Tanaka, D.; Sassenrath, G. Principles of integrated agricultural systems: Introduction to processes and definition. Renew. Agric. Food Syst. 2008, 23, 265-271. [CrossRef]

11. European Commission. Factsheet: From Farm to Fork: Our Food, Our Health, Our Planet, Our Future; European Commission: Brussels, Belgium, 2020.

12. Ministry of Agriculture, Forestry and Fisheries (MAFF). Strategy for Green Food System; Ministry of Agriculture, Forestry and Fisheries: Tokyo, Japan, 2021.

13. Bouttes, M.; Darnhofer, I.; Martin, G. Converting to organic farming as a way to enhance adaptive capacity. Org. Agric. 2019, 9, 235-247. [CrossRef]

14. Ayuya, O.I. Organic certified production systems and household income: Micro level evidence of heterogeneous treatment effects. Org. Agric. 2019, 9, 417-433. [CrossRef]

15. Hansen, B.G.; Haga, H.; Lindblad, K.B. Revenue efficiency, profitability, and profitability potential on organic versus conventional dairy farms-Results from comparable groups of farms. Org. Agric. 2021, 11, 351-365. [CrossRef]

16. Pham, L.; Shively, G. Profitability of organic vegetable production in northwest Vietnam: Evidence from Tan Lac District, Hoa Binh Province. Org. Agric. 2019, 9, 211-223. [CrossRef]

17. Dessart, F.J.; Barreiro-Hurlé, J.; van Bavel, R. Behavioural factors affecting the adoption of sustainable farming practices: A policyoriented review. Eur. Rev. Agric. Econ. 2019, 46, 417-471. [CrossRef]

18. Badu-Gyan, F.; Henning, J.I.; Grové, B.; Owusu-Sekyere, E. Examining the social, physical and institutional determinants of pineapple farmers' choice of production systems in Central Ghana. Org. Agric. 2019, 9, 315-329. [CrossRef]

19. Bui, H.T.M.; Nguyen, H.T.T. Factors influencing farmers' decision to convert to organic tea cultivation in the mountainous areas of northern Vietnam. Org. Agric. 2021, 11, 51-61. [CrossRef]

20. Digal, L.N.; Placencia, S.G.P. Factors affecting the adoption of organic rice farming: The case of farmers in M'lang, North Cotabato, Philippines. Org. Agric. 2019, 9, 199-210. [CrossRef]

21. Sharma, M.; Pudasaini, A. What motivates producers and consumers towards organic vegetables? A case of Nepal. Org. Agric. 2021, 11, 477-488. [CrossRef]

22. Väre, M.; Mattila, T.E.A.; Rikkonen, P.; Hirvonen, M.; Rautiainen, R.H. Farmers' perceptions of farm management practices and development plans on organic farms in Finland. Org. Agric. 2021, 11, 457-467. [CrossRef]

23. Chan, C.; Sipes, B.; Ayman, A.; Zhang, X.; LaPorte, P.; Fernandes, F.; Pradhan, A.; Chan-Dentoni, J.; Roul, P. Efficiency of conservation agriculture production systems for smallholders in Rain-Fed Uplands of India: A transformative approach to food security. Land 2017, 6, 58. [CrossRef]

24. Rudel, T.K.; Kwon, O.-J.; Paul, B.K.; Boval, M.; Rao, I.M.; Burbano, D.; McGroddy, M.; Lerner, A.M.; White, D.; Cuchillo, M. Do Smallholder, mixed crop-livestock livelihoods encourage sustainable agricultural practices? A meta-analysis. Land 2016, 5, 6. [CrossRef] 
25. Bartolini, F.; Vergamini, D. Understanding the spatial agglomeration of participation in agri-environmental schemes: The case of the Tuscany region. Sustainability 2019, 11, 2753. [CrossRef]

26. Morel, K.; Léger, F. A Conceptual framework for alternative farmers' strategic choices: The case of French organic market gardening microfarms. Agroecol. Sustain. Food 2016, 40, 466-492. [CrossRef]

27. Uruma, H.; Kobayashi, R.; Nishijima, S.; Miyashita, T. Effectiveness of conservation-oriented agricultural practices on amphibians inhabiting Sado Island, Japan, with a consideration of spatial structure. Jpn. J. Conserv. Ecol. 2012, 17, 155-164. (In Japanese)

28. Kanazawa, S. No-till farming as sustainable and environment-friendly farming: Crop yeild in dry field and soil characteristics. Jpn. Soc. Soil Sci. Plant Nutr. 1995, 66, 286-297. (In Japanese)

29. Oda, M.; Kiminami, L. Study on the consciousness of the farm households introducing environment-friendly agriculture: Analysis based on the "certification system for the rice of living with Japanese crested ibis" in Sato City, Niigata Prefecture. Niigata Daigaku Nōgakubu Kenkyū Hōkoku 2014, 66, 85-104. (In Japanese)

30. Fujita, M.; Hatano, T. Opportunity and financial status in newly started and transformed organic farmers: Based on the questionnaire surveys from organic farmers. Yūki Nōgyō Kenkyū 2017, 9, 53-63. (In Japanese)

31. Uenishi, Y. Factors affecting the diffusion of conservation-oriented farming methods. J. Rural Probl. 2019, 55, 73-80. (In Japanese) [CrossRef]

32. Buck, D.; Getz, C.; Guthman, J. From farm to table: The organic vegetable commodity chain of northern California. Sociol. Rural 1997, 37, 3-20. [CrossRef]

33. Guthman, J. The trouble with 'organic lite' in California: A rejoinder to the 'conventionalisation'debate. Sociol. Rural. 2004, 44, 301-316. [CrossRef]

34. Suzuki, Y. Sustainability and development of environmentally friendly agriculture in the hilly and mountainous farming areas-A case study of the south Aso and the mountainous region in Kyushu, Japan. Ann. Jpn. Assoc. Econ. Geogr. 1997, 43, 276-292. (In Japanese)

35. Arai, S.; Nishio, M.; Yoshino, T. Connecting with Organic Farming and Living Close to a Community: Development of Yūki Hāto Netto in Shirakawa Town, Gifu Prefecture; Tsukuba Shobō: Tokyo, Japan, 2021. (In Japanese)

36. Anwar, A.; Sarwar, S.; Amin, W.; Arshed, N. Agricultural practices and quality of environment: Evidence for global perspective. Environ. Sci. Pollut. Res. 2019, 26, 15617-15630. [CrossRef]

37. Smith, D.L.; Almaraz, J.J. Climate change and crop production: Contributions, impacts, and adaptations. Can. J. Plant Pathol. 2004, 26, 253-266. [CrossRef]

38. Oenema, O.; Wrage, N.; Velthof, G.L.; van Groenigen, J.W.; Dolfing, J.; Kuikman, P.J. Trends in global nitrous oxide emissions from animal production systems. Nutr. Cycl. Agroecosyst. 2005, 72, 51-65. [CrossRef]

39. Waheed, R.; Chang, D.; Sarwar, S.; Chen, W. Forest, agriculture, renewable energy, and $\mathrm{CO}_{2}$ emission. J. Clean. Prod. 2018, 172, 4231-4238. [CrossRef]

40. Mena, Y.; Gutierrez-Peña, R.; Ruiz, F.A.; Delgado-Pertíñez, M. Can dairy goat farms in mountain areas reach a satisfactory level of profitability without intensification? A case study in Andalusia (Spain). Agroecol. Sustain. Food 2017, 41, 614-634. [CrossRef]

41. Ishikawa Prefectural Government. Preliminary Report of the 2020 Census; Ishikawa Prefectural Government: Kanazawa, Japan, 2021. (In Japanese)

42. Ministry of Agriculture, Forestry and Fisheries (MAFF). Census of Agriculture and Forestry in Japan; Ministry of Agriculture, Forestry and Fisheries: Tokyo, Japan, 2016. (In Japanese)

43. Kohsaka, R.; Tomiyoshi, M.; Matuoka, H. Tourist Perceptions of Traditional Japanese Vegetable Brands: A Quantitative Approach to Kaga Vegetable Brands and an Information Channel for Tourists at the Noto GIAHS Site. In Aquatic Biodiversity Conservation and Ecosystem Services; Nakano, S., Yahara, T., Nakashizuka, T., Eds.; Springer: Singapore, 2016; pp. $109-121$.

44. Kamiyama, C. Food Provisioning Services via Homegardens and Communal Sharing in Satoyama Socio-Ecological Production Landscapes on Japan's Noto Peninsula. In Sharing Ecosystem Services; Saito, O., Ed.; Springer: Singapore, 2020 ; pp. 35-53.

45. Kohsaka, R.; Matsuoka, H. Analysis of Japanese municipalities with Geopark, MAB, and GIAHS certification: Quantitative approach to official records with text-mining methods. SAGE Open 2015, 5, 1-10. [CrossRef]

46. Kohsaka, R.; Ito, K.; Miyake, Y.; Uchiyama, Y. Cultural ecosystem services from the afforestation of rice terraces and farmland: Emerging services as an alternative to monoculturalization. For. Ecol. Manag. 2021, 497, 119481. [CrossRef]

47. Ministry of Agriculture, Forestry and Fisheries (MAFF). About the Situation of Organic Agriculture; Ministry of Agriculture, Forestry and Fisheries: Tokyo, Japan, 2020. (In Japanese)

48. Kotrlik, J.; Higgins, C. Organizational research: Determining appropriate sample size in survey research appropriate sample size in survey research. Inf. Technol. Learn. Perform. J. 2001, 19, 43.

49. Quevedo, J.M.D.; Uchiyama, Y.; Lukman, K.M.; Kohsaka, R. How blue carbon ecosystems are perceived by local communities in the coral triangle: Comparative and empirical examinations in the Philippines and Indonesia. Sustainability 2021, $13,127$. [CrossRef]

50. Ministry of Agriculture, Forestry and Fisheries (MAFF). A National Survey through the Network Scheme to Communicate the Information of Agriculture, Forestry, and Fisheries in the Year Heisei 27: The Survey of Awareness and Intention About Environmentally Friendly Agricultural Products Including Organic Ones; Ministry of Agriculture, Forestry and Fisheries: Tokyo, Japan, 2016. (In Japanese)

51. Ministry of Agriculture, Forestry and Fisheries (MAFF). Label Guideline about Specially Cultivated Agricultural Products; Ministry of Agriculture, Forestry and Fisheries: Tokyo, Japan, 2020. (In Japanese) 
52. Ministry of Agriculture, Forestry and Fisheries (MAFF). Annual Report on Food, Agriculture and Rural Areas in Japan FY2019; Ministry of Agriculture, Forestry and Fisheries: Tokyo, Japan, 2020. (In Japanese)

53. Ministry of Health, Labour and Welfare. HACCP, n.d. Available online: https://www.mhlw.go.jp/stf/seisakunitsuite/bunya/ kenkou_iryou/shokuhin/haccp/index.html (accessed on 19 January 2021). (In Japanese)

54. Japan Patent Office. Regional Collective Trademark System, n.d. Available online: https://www.jpo.go.jp/e/system/trademark/ gaiyo/chidan/ (accessed on 19 January 2021). (In Japanese)

55. Ito, J.; Feuer, H.N.; Kitano, S.; Asahi, H. Assessing the effectiveness of Japan's community-based direct payment scheme for hilly and mountainous areas. Ecol. Econ. 2019, 160, 62-75. [CrossRef]

56. Miyake, Y.; Kohsaka, R. Discourse of quality and place in geographical indications: Applying convention theory to Japanese tea. Food Rev. Int. 2022, 1-26. [CrossRef]

57. Best, H. Organic Agriculture and the conventionalization hypothesis: A case study from west Germany. Agric. Hum. Values 2008, 25, 95-106. [CrossRef]

58. Giménez Cacho, M.M.T.; Giraldo, O.F.; Aldasoro, M.; Morales, H.; Ferguson, B.G.; Rosset, P.; Khadse, A.; Campos, C. Bringing agroecology to scale: Key drivers and emblematic cases. Agroecol. Sustain. Food 2018, 42, 637-665. [CrossRef]

59. Baker, B.P.; Meints, B.M.; Hayes, P.M. Organic barley producers' desired qualities for crop improvement. Org. Agric. 2020, 10, 35-42. [CrossRef]

60. Matsuzawa, T.; Kohsaka, R. Status and trends of urban beekeeping regulations: A global review. Earth 2021, 2, 933-942. [CrossRef]

61. Matsuzawa, T.; Kohsaka, R. Preliminary experimental trial of effects of lattice fence installation on honey bee flight height as implications for urban beekeeping regulations. Land 2022, 11, 19. [CrossRef]

62. Kohsaka, R.; Miyake, Y. The politics of quality and geographic indications for non-timber forest products: Applying convention theory beyond food contexts. J. Rural Stud. 2021, 88, 28-39. [CrossRef]

63. Bliss, K.; Padel, S.; Cullen, B.; Ducottet, C.; Mullender, S.; Rasmussen, I.A.; Moeskops, B. Exchanging knowledge to improve organic arable farming: An evaluation of knowledge exchange tools with farmer groups across Europe. Org. Agric. 2019, 9, 383-398. [CrossRef]

64. Chabe-Ferret, S.; Le Coent, P.; Reynaud, A.; Subervie, J.; Lepercq, D. Can we nudge farmers into saving water? Evidence from a randomised experiment. Eur. Rev. Agric. Econ. 2019, 46, 393-416. [CrossRef]

65. Kohsaka, R.; Tomiyoshi, M.; Saito, O.; Hashimoto, S.; Mohammend, L. Interactions of knowledge systems in shiitake mushroom production: A case study on the Noto Peninsula, Japan. J. For. Res.-Jpn. 2015, 20, 453-463. [CrossRef]

66. Miyake, Y.; Uchiyama, Y.; Kohsaka, R. Status and trends of urban organic agricultural policy in Japan: The survey on ordinance designated cities. Org. Agric. 2020, 10, 497-508. [CrossRef]

67. Willer, H.; Travnicek, J.; Meier, C.; Schlatter, B. (Eds.) The World of Organic Agriculture: Statistics and Emerging Trends 2021; Research Institute of Organic Agriculture: Frick, Switzerland; Organics International: Bonn, Germany, 2021.

68. Kizos, T.; Koshaka, R.; Penker, M.; Piatti, C.; Vogl, C.R.; Uchiyama, Y. The governance of geographical indications. Br. Food J. 2017, 119, 2863-2879. [CrossRef]

69. Tashiro, A.; Uchiyama, Y.; Kohsaka, R. Impact of geographical indication schemes on traditional knowledge in changing agricultural landscapes: An empirical analysis from Japan. J. Rural Stud. 2019, 68, 46-53. [CrossRef]

70. Miyake, Y.; Kohsaka, R. History, ethnicity, and policy analysis of organic farming in Japan: When "nature" was detached from organic. J. Ethn. Foods 2020, 7, 1-8. [CrossRef] 